\title{
White-Collar Crime and Criminal Careers
}

\author{
Specifying a Trajectory of Punctuated Situational Offending
}

NICOLE LEEPER PIQUERO

University of Florida

MICHAEL L. BENSON

University of Cincinnati

\begin{abstract}
The life course approach to the study of criminal careers has achieved a prominent place in criminology. Life course researchers have identified several distinct patterns in criminal offending and provided several provocative explanations to account for them. Noticeably lacking in the study of life course criminology, however, is any recognition of white-collar offenders. The typical whitecollar offender greatly differs from the typical street offender and does not appear to fit into the proposed explanations of life course offending patterns. Recently, some scholars have applied the techniques and terminology of the criminal career perspective to white-collar offending. This article reviews the current state of developmental theories as they apply to life course offending patterns, summarizes what is known about the intersection of white-collar crime and criminal careers, and suggests ways in which the current theoretical understandings of crime over the life course can be modified to account for white-collar crime patterns.
\end{abstract}

Keywords: white-collar crime; life course; criminal careers; trajectories; age; crime

$\mathbf{T}$

The rise of the life course approach has been a breath of fresh air for criminology. Even though it is a relatively recent development, it has already produced a number of significant results (for many examples, see the articles in Thornberry \& Krohn, 2003). More important, it has provided a new way of looking at offenders, a more realistic view that recognizes that behaviorespecially the behavior of young people-results from complex, multifaceted, and interacting developmental processes. Despite its accomplishments and its promise, however, life course criminology runs the risk of making an old mistake, a mistake pointed out long ago by Sutherland (1940). The mistake is acting as though common street crime is the only type of crime there

Journal of Contemporary Criminal Justice, Vol. 20 No. 2, May 2004 148-165 DOI: $10.1177 / 1043986204263770$

(C) 2004 Sage Publications 
is. Sutherland criticized the criminologists of his day for relying on samples limited to street offenders, for having an overly narrow conception of offending and offenders, and for ignoring illegalities that did not conform to the common stereotypical image of street crime. Exactly the same charges could be leveled today at life course criminology. With very few exceptions, it too has relied on limited samples; it too implicitly conveys the impression that juvenile delinquency and street crime are the only forms of crime there are; and it too neglects the crimes of the powerful and well-to-do. ${ }^{1}$ If continued, these practices will, we argue, inevitably lead to a biased and incomplete understanding of trajectories in crime.

The developmental explanations that have been put forth to explain offending patterns over the life course assume that offending almost always begins early in life, that is, sometime during the first or second decade of life. The primary issues that researchers have investigated are age at which offending starts, how long it lasts, and how the age of onset relates to the length of career. One important theory posits that there are only two general patterns: those who show signs of antisocial behavior very early in life and persist in antisocial and criminal behavior throughout adulthood versus those who show no signs of antisocial behavior early but who undergo a brief period of criminality during adolescence (Moffitt, 1993; also see Patterson, DeBaryshe, \& Ramsey, 1989). That such patterns are followed by many individuals is undoubtedly true, but there is another pattern that has been left out of the picture. It includes those who seem to begin or, as we argue, resume offending in adulthood, presumably after most other offenders have "aged out" of crime. Existing theoretical models have yet to acknowledge, let alone account for, this group of offenders.

\section{Life Course Criminology}

The relationship between age and crime is one of the oldest and most studied phenomena in criminology (Piquero, Farrington, \& Blumstein, 2003). The life course perspective offers a new way of viewing this relationship by focusing on how events, both legal and illegal, occur sequentially over time in people's lives and on how developments in one domain of life can influence the timing and sequencing of events in other domains. Elder (1994) describes the life course as a series of age-graded trajectories and transitions that occur throughout an individual's life span (p. 5). A trajectory is a sequence of linked states within a conceptually defined realm of behavior or development. For example, one can have an educational trajectory, an occupational trajectory, or as most concerns us here, a criminal trajectory. With respect to trajectories in crime, criminologists have applied the life course perspective to patterns in individual involvement in crime with specific attention to the 
initiation, continuation, and termination of offending behaviors (LeBlanc \& Loeber, 1998). Transitions refer to changes in state within a trajectory. Again, sticking with trajectories in crime, committing one's first offense is an important transition in one's criminal trajectory. Indeed, it marks the onset or entrance into this trajectory. Moving from group-oriented to solo offending, which sometimes happens as offenders get older, would represent another sort of transition in a trajectory in crime. Transitions often represent turning points or change in the life course and hence are especially important matters to study.

Researchers working in the criminal career and life course perspectives have paid most attention to four interrelated aspects of trajectories in crime. These aspects include the onset of offending, duration of offending career, desistance from offending, and patterns in the types of offenses committed by offenders while they are active. With regard to the onset of offending, investigators have consistently found that for most people, involvement in crime and delinquency begins in the midteenage years, usually sometime between ages 15 and 17 (Elliot, 1994; West \& Farrington, 1977). A small proportion of individuals start earlier and a few start later, but it is very unusual for someone to embark for the first time on a trajectory in street crime after the age of 25 . Research also shows that for most people, career duration - that is, the period of active criminality - is short and is over by the time they reach the age of 20 (Blumstein, Cohen, Roth, \& Visher, 1986). Except for a small number of offenders, desistance from street crime usually occurs sometime in the early 20s (Blumstein et al., 1986).

Moffitt (1997) argues that individuals who are still involved in street crime after their mid-20s are life-course-persistent offenders. In her view, these individuals start offending earlier than normal and continue to offend at high rates for much longer than individuals who follow the normal adolescencelimited trajectory. Early analyses of longitudinal offending patterns tended to confirm Moffitt's approach and identified three distinct groups: nonoffenders, one-time or short-term offenders, and long-term chronic offenders. However, as researchers have more closely examined offending trajectories using sophisticated statistical techniques, another pattern has been identified. Nagin and Land (1993) discovered evidence that the group of chronic offenders may contain two subgroups: high-rate and low-rate chronics. The members of the low-rate chronic group were distinguished by the longevity of their criminal careers and by a flatter age-crime curve. During their teenage years, the low-rate chronics commit offenses at a rate that actually may be lower than the rate for short-term offenders. However, unlike the short-term offenders, the low-rate chronics continue to offend after age 20. By age 30, their offense rate appears similar to that of the high-rate chronic offenders at the same age. Thus, the trajectory of the low-rate chronic 
group does not appear to follow the typical age-crime curve. They have much flatter curves than are normal (Nagin \& Land, 1993). In summary, although investigators disagree on the exact number of trajectories in crime, they all agree that offending starts either during or shortly before the teenage years, and therefore, explanations of trajectories in crime tend to focus on causal factors that are active during or before that time period.

\section{Developmental Theories}

In searching for theoretical explanations for the observed patterns in agerelated involvement in crime, theorists have articulated and tested developmental theories of criminal and antisocial behavior. As a whole, developmental theories attempt to explain crime in the context of the life course, that is, they build off the assumption that factors that affect offenders change as offenders age (Vold, Bernard, \& Snipes, 1998).

Moffitt (1993) draws from various criminological perspectives to account for the offending behaviors of what she has identified as two distinct groups of offenders: the life course persistent and the adolescence limited. A combination of biology and socialization are at the heart of her theory. Regardless of the path that is followed, antisocial behavior is assumed to start early in life, either early in childhood or later in adolescence. Moffitt argues that when antisocial behavior is displayed very early, it is the result of certain neuropsychological deficits (e.g., cognitive deficiencies, difficult temperament, hyperactivity, etc.) in the child. By themselves, these deficits are not enough to launch an individual on the life-course-persistent trajectory. Rather, environmental factors in the form of abusive or inadequate parenting are posited to interact with the neuropsychological deficits. When both factors are present, youths become hard to discipline and train. Lacking proper socialization early, these individuals fail to establish conventional bonds to society, such as attachment to parents or to school, and are not likely to develop them in adulthood (however, see Sampson \& Laub, 1993). The antisocial behavior that these individuals exhibit early in life soon develops into full-blown delinquency and criminality. This behavioral pattern continues and escalates in seriousness throughout adolescence and early adulthood.

The onset of offending for those who follow the adolescence-limited trajectory is believed to coincide with biological maturation during the adolescent years. In today's world, youths mature physically long before they do socially or legally. Moffitt (1993) refers to this as the "maturity gap" and suggests that during this period of adolescent limbo, which runs roughly from ages 14 to 18 , youths want to be independent and to be treated as mature adults. But parents, teachers, and society in general do not view them as yet fully ready for autonomy and continue to place limits on their behavior and 
freedom. According to Moffitt, youths rebel against this treatment by acting as though they are indeed independent and by engaging in minor forms of delinquency-smoking, drinking, illicit sex, and vandalism. Moffitt argues that adolescent-limited offenders learn how to be delinquent by mimicking the behavior of the life-course-persistent offenders. Nonconforming behaviors allow youths to demonstrate autonomy while awaiting adult societal opportunities. Eventually, as adolescence-limited offenders get older and acquire the privileges of age, the need for and the attractiveness of delinquency declines and they stop participating in such activities. Thus, the lifecourse-persistent trajectory illustrates continuity in offending, but the adolescence-limited trajectory manifests change.

Unlike Moffitt's developmental explanation, Sampson and Laub's (1993) theoretical approach does not suggest different pathways to delinquency but rather offers an age-graded theory of informal social control to explain both continuity and change in offending behavior over the life course. Derived from social control theory, the theory developed by Sampson and Laub (1993) posits that social bonds are the mechanism that accounts for change or lack of change in crime trajectories. Regardless of the stage of life, as social bonds strengthen or weaken, criminal behavior correspondingly increases or decreases.

For Sampson and Laub (1993), the onset of criminal behavior can be traced back to early childhood socialization. Adolescents that fail to establish strong ties to conventional institutions such as family, school, and peers early in life are more likely to engage in delinquency and crime. The transition from adolescence to adulthood can lead either to continuity in offending or change in behavioral patterns. Some juvenile delinquents will continue to offend well into adulthood, whereas others will cease antisocial behaviors altogether. Stability in offending behavior results because delinquency in childhood has a causal effect on adult bonds; that is, it effectively cuts off opportunities to develop and establish prosocial bonds in adulthood. Therefore, the pattern of antisocial behavior is hypothesized to continue as long as prosocial controlling factors are absent. Some juveniles are able to overcome their troubled backgrounds and go on to live a conventional, law-abiding life. They experience "turning points," which include such fortuitous events as making a good marriage, finding stable employment, or undergoing military service. Desistance in offending behavior, then, occurs because salient life events and socialization experiences in adulthood can counteract the negative influences of childhood delinquency (Sampson \& Laub, 1993). Because individuals are able to become socially bonded at any age, through investments or attachments to conventional institutions, it is believed that social bonds are the mechanism that works to deter criminal activity at any point in the life course. 
Thornberry (1987) presents an explanation of offending over the life course that combines elements from social control theory and social learning theory. Like Moffitt, he argues that there are multiple paths to delinquency, but otherwise the thrust of his interactional theory is very similar to that presented by Sampson and Laub. As with their approach, social control theory provides the foundation for his theoretical explanation. He argues that when social constraints are absent or relaxed, juveniles are more likely to take advantage of opportunities for crime or delinquency. However, the availability of opportunities for delinquency does not necessarily mean it will happen; first, delinquency must be learned. Drawing from social learning theory, Thornberry (1987) argues that for juveniles to acquire delinquent behaviors and skills, they need an interactive setting in which such behavior can be learned, performed, and reinforced. He presents three models of adolescent offending: one focusing on early adolescence (11-13), one for middle adolescence (15-16), and one for late adolescence (18-20). The three models are similar with the main difference being the age-related variables that constrain antisocial behaviors at the various ages depicted in the models. Parents and family are most important in early life, but they give way to school and peers in adolescence. Peers, in turn, become less salient than intimate partners and occupational outcomes in late adolescence.

One final approach to studying criminal careers is offered by Hagan and Palloni (1998, p. 90). They suggest that a broader conceptualization of criminal careers is needed. Rather than focusing on a limited number of years- the peak years of offending in late adolescence or early adulthood as is done by most developmental theorists - they suggest that the focus needs to be on the entire life course and not just on the criminal trajectory. They draw attention to the causes and consequences of "social events," such as delinquent or criminal acts, and the effect of these events over the entire life course. For example, participation in delinquent or criminal acts may have consequences for the rest of an individual's life. These consequences may include reduced educational and occupational opportunities. Because they argue that most individuals do not have "criminal careers" but rather just episodes of delinquent or criminal acts, we need to be more concerned with the larger picture and with the influence of these events on future life chances.

Building off of this alternative approach, Hagan (1997) developed a theoretical model of crime over the life course in which he argued that all studies of delinquency are more or less explanations of offending over an individual's life because the consequences of delinquent acts can easily shift trajectories in other domains. Drawing from strain and subcultural perspectives, he argues that a delinquent youth subculture permits adolescents with an "escape" from socioeconomically induced feelings of distress, so much so that the youths do not notice or recognize their negative emotions. Because 
the central pursuit of most youths is to have fun, he argues that negative feelings, primarily despair or hopelessness, do not kick in until later in life. Becoming enmeshed in a delinquent rebellious subculture has a "sleeper effect" that does not fully emerge until midlife.

Existing developmental explanations of offending behavior offer many useful approaches for explaining involvement in street crime over the life course, largely because they are able to address several of the important dimensions of the criminal career (Blumstein et al., 1986). For example, these theories not only provide plausible accounts of the onset of offending, they also provide explanations for the persistence of and eventual desistance from offending behaviors. Despite the various underlying assumptions and number of proposed pathways to crime, the common thread running throughout existing life course explanations is that the onset or catalyst of criminal behavior occurs relatively early in life (e.g., early childhood or during adolescence) but certainly not after adolescence. Moffitt, Caspi, Rutter, and Silva (2001) even state that the "onset of antisocial behavior after adolescence is extremely rare" (p. 85). Therefore, these developmental theories, in their current state, cannot account for the group offenders who appear to begin offending later in life (i.e., adulthood), namely, white-collar criminals. ${ }^{2}$

\section{White-Collar Crime and Criminal Careers:}

What Do We Know?

A statistically valid picture of white-collar offenders is hard to come by because of the virtual lack of quantitative data on these offenders. Until the late 1980s, most of what was known about white-collar offenders was based on qualitative accounts of highly publicized and egregious offenders and offenses (Benson, 2002). Following Sutherland's lead, investigators conducted detailed case studies of the offenses of powerful upper-class business executives from the privileged sectors of society (e.g., Braithwaite, 1984; Calavita \& Pontell, 1990; Geis, 1977; Simpson \& Piquero, 2000). ${ }^{3}$ The case study approach has done much to keep white-collar crime on the criminological map, and it has confirmed many of Sutherland's original conjectures concerning the high social status of the offenders, the seriousness of their offenses, and the leniency of their treatment in the justice system.

In the 1980s, two data collection efforts were undertaken that for the first time permitted statistical analyses of the characteristics of white-collar offenders, offenses, and offending careers. The first dataset was constructed under the guidance of Stanton Wheeler (Wheeler, Weisburd, Waring, \& Bode, 1988). The other dataset was collected by Brian Forst and William Rhodes. Both studies were based on samples of individuals who had been convicted in selected U.S. federal courts of presumptively white-collar 
crimes in the mid-1970s. In the Wheeler dataset, the white-collar offenses included antitrust offenses, securities fraud, mail fraud, false claims, bribery, income tax fraud, lending and credit fraud, and bank embezzlement with a sample size of 1,342. In the Forst and Rhodes data, the white-collar offenses included embezzlement, bribery, income tax fraud, false claims, and mail fraud with a sample size of 2,462. Data were collected from presentence investigation (PSI) reports, which are prepared by federal probation officers after an offender is convicted for the sentencing judge (for more complete information on the sampling designs and data collection methods, see Forst \& Rhodes, n.d.; Weisburd, Wheeler, Waring, \& Bode, 1991). The PSI report provides detailed information on the current offense, criminal history, and background characteristics of offenders (e.g., education, employment, family, etc.). Although both studies were originally designed to investigate how white-collar offenders were treated in the federal judicial system, the quality and depth of information available from the PSIs permitted investigators to examine the social characteristics of the offenders and various aspects of their offending careers (Benson \& Kerley, 2000; Benson \& Moore, 1992; Weisburd \& Waring, 2001; Weisburd et al., 1991; Wheeler et al., 1988). It is important that both studies also sampled a comparison group of individuals convicted of non-white-collar offenses, enabling comparisons between individuals who commit different types of offenses.

A great deal has been learned from these data collection efforts that challenges existing assumptions in the study of white-collar crime and criminal careers. For example, two notable findings emerged that call into question the stereotype of the white-collar offender as a person of wealth, power, and high social status, who has led an upstanding and otherwise impeccable life. First, most of the individuals convicted of white-collar crimes in the federal system are not wealthy high-powered corporate executives. Rather, they tend to look more like members of the middle classes with moderate incomes and ordinary jobs-small-time entrepreneurs and midlevel office workers (Benson \& Kerley, 2000; Weisburd et al., 1991). Second, a substantial proportion of persons convicted of white-collar offenses are repeat offenders, that is, they have had at least two official contacts with the criminal justice system (Benson \& Moore, 1992; Weisburd et al., 1991). In both studies, approximately $40 \%$ of the white-collar offenders had at least one other arrest in addition to the white-collar type offense that made them eligible for inclusion in the study.

Even though in these studies white-collar offenders turn out to be not as elite or law abiding as the standard stereotype would envision them, there are still substantial differences between white-collar and common offenders. After carefully comparing the persons convicted of ordinary street crimes 
with those convicted of white-collar crimes on a host of social background and status characteristics, Weisburd and his colleagues (1991) concluded that

whatever else may be true of the distinction between white-collar and common criminals, the two are definitely drawn from distinctively different sectors of the American population. (p. 73)

Similar analyses of the Forst and Rhodes data came to the same conclusion (Benson \& Kerley, 2000; Benson \& Moore, 1992). The people who commit white-collar crimes do not come from the same social backgrounds nor occupy the same social space as the people who commit ordinary street crimes. To the extent that criminal careers are seen as arising out of one's social background, these offenders offer a challenge to existing developmental theories of criminal offending.

In an important follow-up study based on the Wheeler data, Weisburd and Waring (2001) gathered additional data on the subsequent criminal records of the original Wheeler sample. Using FBI rap sheets, the investigators were able to construct longitudinal criminal record data on the offenders that ran from the time of their original white-collar crime convictions in the mid1970s up to 10 years later. They found that almost one third of the white-collar offenders were rearrested after their original convictions (p. 28).

An important issue for life course criminology and for the criminal career paradigm is the age of onset. As noted above, research based on ordinary street offenders and juvenile delinquents finds that most of these offenders have official contacts with the justice system sometime in their teenage years. However, for white-collar criminals, the average age of onset is found to be substantially later. In the Wheeler data, the average age of onset, defined as an arrest, for all white-collar offenders was 35 . Of course, many of the whitecollar offenders were first-time offenders, but even when the sample is restricted to offenders with at least two arrests, the average age of first arrest for white-collar offenders is 33.5. For first-time offenders, the average age is 40.9 (Weisburd \& Waring, 2001, pp. 33-34). Benson and Kerley (2000, p. 132) found exactly the same average age of onset (40) for first-time white-collar offenders as in the Forst and Rhodes data. For white-collar offenders with prior records, the average age of onset was 24 compared to 19 for common offenders.

When and how offenders end their criminal careers also are important questions for the criminal career perspective. Weisburd and Waring (2001) examined the issue of desistance for white-collar offenders. They found notable differences between white-collar and common offenders with regard to desistance. The average age of last arrest for repeat white-collar offenders 
in their study was 43 , considerably older than the late 20 s and early 30 s, which is the time period during which most common offenders are assumed to age out of crime. It is surprising that a substantial number of the repeat offenders in their sample were arrested in their 50s, and a small number of offenders continued to be active into their 70s (Weisburd \& Waring, 2001, p. 37).

Weisburd and Waring (2001) also found other differences between the careers of their white-collar offenders and the careers of street offenders. For instance, the repeat offenders in their sample had on average considerably longer periods of career activity than is typically found in samples of street offenders. Research on street offenders typically finds that criminal careers last not much longer than 5 years (Farrington, 1992). Among the white-collar offenders studied by Weisburd and Waring, however, the average duration between first and last arrest was 14 years. In addition, even though these white-collar offenders were criminally active for relatively long periods of time, they tended to commit, or at least to be arrested for, relatively few offenses during the duration of their careers. As Weisburd and Waring (2001) note, in light of their relatively low levels of criminal activity, it may not even make sense to apply the concept of criminal career to white-collar offenders (p. 43).

One area in which those who commit white-collar offenses do appear to be similar to those who commit ordinary street offenses is in their lack of specialization in offending. Although a large proportion of white-collar offenders are repeat offenders, in the sense of having other arrests, their other offenses tend not to be other white-collar crimes (Benson \& Moore, 1992; Weisburd \& Waring, 2001). Rather, they are arrested for a variety of other types of crimes. At least as indicated by arrests, white-collar offenders do not specialize in white-collar crimes to any notable degree. Of course, it is entirely possible that successful white-collar offenders specialize in one type of offense but are simply never caught.

On such limited evidence, it would, of course, be unwise to draw many firm conclusions about the criminal careers or absence of criminal careers of white-collar offenders. We simply need more data. The two most useful datasets available are now more than 20 years old, and no effort has been made to gather data on contemporary white-collar offenders. Nevertheless, we can make two observations that we think are likely to stand the test of time and new data. First, the people who commit white-collar crimes come from more privileged or less troubled social and personal backgrounds than the people who commit ordinary street crimes. Second, white-collar offending starts and ends later in the life course than street crime. Although these observations may appear blazingly obvious to some, their significance for life course and developmental approaches to crime should not be overlooked. To 
the extent that these approaches emphasize biological and early family background factors in the etiology of crime, it would seem that they are going to have difficulty accounting for patterns in white-collar offending.

\section{Theoretical Expansions to Account for White-Collar Offenders}

To date, our understanding or picture of trajectories in crime assumes that offending starts early in life, stops after a short while for most people, but continues on longer for a small subset of offenders. We suspect that this view misses another potential pattern, a pattern that is followed by those who become involved in white-collar crime. We call this pattern punctuated situationally dependent offending. ${ }^{4}$ This pattern assumes that white-collar offenders follow the same developmental trajectories in crime and delinquency that most people do. That is, they have a brief flirtation with delinquency during adolescence that ends in the late teens or early 20s. However, after a period of conformity during their 20s and 30s, they begin to offend again later in life by committing white-collar crimes. Their offending is situational in the sense that it is triggered by or dependent on factors external to the offender. This situational dependence can come about in two ways. First, white-collar offending may be situationally dependent in the sense that the opportunity to offend may not become available to the individual until after he or she has obtained a certain occupational position. Second, it may be situationally dependent in the sense that the individual experiences some crisis in his or her personal or occupational life that motivates the commission of a white-collar crime. The key point about this pattern, however, is that it is not a continuation of the offending that took place during adolescence. Rather, the offender's criminal trajectory is punctuated by a period or periods of conformity, and when offending resumes, it is of a different character from the indiscretions of youth.

Existing developmental explanations do not account for this punctuated period of conformity, nor do they address the resumption of criminal activity. In fact, two common themes running throughout existing life course explanations are that offending begins early in life and that once offenders have become socially integrated into conventional society, criminal activities will be forever deterred. It would appear then that white-collar offenders, who begin offending in adulthood and who are already educated, employed, and married, offer a unique challenge to life course explanations of criminal behavior, particularly with regard to onset and desistance of offending. We offer below some suggestions for orienting future investigations and a challenge to white-collar crime and life course scholars to begin to address this seemingly unique pattern of behavior. 
Unlike street crime opportunities, which are often assumed to be ubiquitous and available to all, opportunities to engage in white-collar crime are not likely to be so prevalent or so democratically distributed. Rather, they arise out of certain occupational positions (Weisburd \& Waring, 2001). Access to white-collar crime opportunities, therefore, is shaped by the same structural factors that determine how occupations are distributed to individuals. Structurally shaped opportunities play a much bigger role in white-collar as opposed to street crime. Criminological theories typically assume the presence of opportunities and do little to articulate how offenders and opportunities come together in time and space (however, see Cohen \& Felson, 1979). For example, Gottfredson and Hirschi (1990) have garnered much attention with respect to both street offending as well as white-collar crime with their general theory of crime. The basic premise of their theory is that variation in an internal trait explains variation in offending; that is, individuals with low self-control will engage in more crime than individuals with greater self-control. Very little attention is paid to explaining or conceptualizing opportunities to offend. It is simply assumed that opportunities for offending are more or less a constant for everyone. White-collar and corporate crime scholars, on the other hand, are acutely aware of how opportunities for white-collar crime are situated within occupations and organizations and their corresponding commercial, economic, and legal environments (Simpson \& Piquero, 2002).

As middle- and upper-class individuals grow older, they are exposed to different kinds and perhaps more white-collar criminal opportunities as they move into more trusted occupational positions. Because potential white-collar criminals have worked their way up to positions of trust and authority, they have unique opportunities to engage in crime that are not available to others. Because so many jobs are now located in large organizations, it is important to consider how organizations influence individual behavior. The structure and culture of an organization may influence how individuals perceive and take advantage of criminal opportunities. An organization may not only expose individuals to various criminal opportunities but may also encourage them in different ways. For example, the hierarchical division of labor and diffuse decision making found in many organizations permits individuals to hide behind the company "web" to avoid being held responsible (Coleman, 1998, p. 133). In addition, the organization may encourage employees through awards and promotional incentives to find innovative solutions to meet company needs (Reed \& Yeager, 1996). Obviously, the study of organizational behavior is a large and complex topic, one that is beyond the scope of this article. We merely wish to note that organizations create both opportunities for white-collar crime and pressure to take advantage of those opportunities. Hence, organizations are an important situational element in white-collar offending, an element that comes into play at a 
different stage in the life course from the usual causal factors associated with crime.

Another important consideration is that unlike many ordinary street crime offenders, white-collar offenders often have acquired some level of material, occupational, and social success. In other words, they have something to lose. We usually think of these trappings of success and achievement as factors that promote conformity. In theory, middle-class people conform in part because they have a stake in conformity and the collateral consequences of being caught doing something untoward are more severe for them than they are for someone who has not achieved middle-class levels of success and who has less to lose. However, situations may arise in which these very same factors can motivate crime rather than conformity. If, for example, the individual experiences some sort of personal or occupational crisis that threatens their middle-class standing, white-collar crime may appear as a way out of the crisis (Benson \& Moore, 1992; Cressey, 1953; Weisburd \& Waring, 2001; Wheeler, 1992). Evidence suggests that some white-collar offenders, particularly women, are likely to respond to family emergencies and poor family economic conditions by engaging in crime (Daly, 1989; Zietz, 1981). Weisburd and Waring (2001) found that a substantial proportion of the whitecollar offenders they studied appeared to fit this pattern. That is, they were people who had gotten into a troublesome situation and who thought that white-collar crime was the only way out. Stanton Wheeler (1992) describes this factor as the fear of falling. He argues that the reasons for engaging in criminal activities may not lie with greed or financial gain but rather with the fear of losing what one has already attained. Individuals in the middle or upper classes have invested much time and effort into conventional society and when things start to go astray, they will grasp onto what they have already worked so hard to attain. Therefore, it is not necessarily the fear of failing but rather the fear of falling that explains some white-collar offending (Wheeler, 1992).

Theoretical expansions always make evident the need for more research. Although we do not claim to have provided a major theoretical expansion here, we do think that our approach recommends several fruitful avenues for research. First, at the most basic level, we simply need more information about the life histories of individual white-collar offenders. Do they really conform to the punctuated pattern that we have hypothesized? That is, is it really true, as we theorized, that most white-collar offenders engage in minor delinquencies during adolescence, then stop, and then start again much later with white-collar offenses? Or, is there some other pattern? Second, if the pattern of punctuated offending is observed, then we need more information on the situational factors that trigger offending later in life. The groundbreaking work by Weisburd and Waring (2001) is very helpful, but it is limited in 
that it is based on a sample of convicted offenders. By definition, these are people who have responded to situational pressures with offending, but the question we really need to answer is this: Of those who experience situational pressures, how many respond to the pressure with offending? And further, what separates those who respond with offending from those who do not? Third, we speculate that a lot of the pressure arises from organizational and job-related influences. So, it is important to document that and better understand just how organizations exert pressures on individuals. A potentially useful line of investigation would be to compare employees or managers in law-abiding companies to their counterparts in companies that are known to have been involved in white-collar offenses. If our theory is correct, then we should expect to observe differences between these individuals in the pressures they feel from the company's leaders. Fourth, future research needs to further explore the role of individual motivations. It very well could be that the motivations for white-collar offending are similar to the motivations for street offending, or it could be that researchers have yet to tap into the full array of individual factors. For example, white-collar crime may simply be a means to alleviate stressful experiences as suggested by traditional strain theories or yet unexplored individual characteristics, such as fear of falling, could better account for such criminal events. These are among the many research avenues to be explored by the intersection between the criminal career paradigm and the existing white-collar crime research.

\section{SUMMARY AND CONCLUSION}

In a number of ways, white-collar crime is different from ordinary street crime. Involvement in it occurs at a different point in the life course. It has a dramatically different opportunity structure. Those who participate in it are drawn from a different sector of the American social structure. Finally, it may have significantly different motivations from those who engage in street crime.

We are not the first to draw attention to the differences between white-collar crimes and street crimes nor are we the first to note that most criminological theories fail to account for white-collar offending behaviors (Sutherland, 1949). Although existing developmental theories may eventually be able to account for developmental patterns in juvenile offending, they appear to have little to offer with regard to crimes that occur later in life, such as white-collar crimes. Most of the theorizing about crime over the life course simply ignores white-collar crime and white-collar crime research. We think this is a mistake. A full understanding of crime over the life course will require criminologists to take a closer look at all forms of offending, including those that 
begin, persist, and end during adulthood. In our view, white-collar offending cannot be explained by the theoretical perspectives currently popular in life course criminology. Rather, a new perspective is needed, one that focuses on adults and on the intersection of occupations, organizations, and white-collar criminal opportunities. Toward that end, we have offered a way of conceptualizing white-collar criminal careers that takes note of the punctuated situationally dependent nature of white-collar offending.

\section{NOTES}

1. Crimes of the elite can include both white-collar crimes, those crimes committed for the benefit of the individual, or corporate crimes, those crimes committed for the benefit of the corporation or organization (Clinard \& Quinney, 1973). Although it is recognized that organizations are held accountable and responsible for the actions of their employees and therefore possible to study the criminal careers of organizations (see Simpson \& Koper, 1992), this is beyond the scope of this article. Our focus will remain on individual actors engaging in criminal behaviors, even though they may on occasion be acting in the interests of an organization.

2. Two life course theories have potential for explaining adult onset but as currently formulated do not explicitly do so. Sampson and Laub (1993) largely emphasize how the development of social bonds in early adulthood can change a criminal trajectory to a law-abiding one but also suggest that the weakening of social bonds would seem to have the potential to permit a law-abiding trajectory to change into a criminal one. Hagan's (1997) notion of a "sleeper effect" could be further explored to account for adult onset of offending.

3. There are exceptions, of course; studies by Cressey (1953) and Zietz (1981) portrayed the lives of white-collar offenders who often came from middle- or even lower class backgrounds. See also Croall (1989).

4. Those familiar with the work of Steven Jay Gould (2002) undoubtedly will not miss that our term echoes the evolutionary theory of punctuated equilibrium that he and Niles Eldredge proposed in 1972. The echo is intentional, in that we speculate that for many white-collar offenders their offenses are episodic events that occur within a background of conformity, just as for Gould major evolutionary changes occur suddenly and episodically within a long time frame of stasis and lack of change.

\section{REFERENCES}

Benson, M. L. (2002). Crime and the life course. Los Angeles: Roxbury Publishing Co.

Benson, M. L., \& Kerley, K. R. (2000). Life course theory and white-collar crime. In H. N. Pontell \& D. Shichor (Eds.), Contemporary issues in crime and criminal justice: Essays in honor of Gilbert Geis (pp. 121-136). Upper Saddle River, NJ: Prentice Hall. 
Benson, M. L., \& Moore, E. (1992). Are white-collar and common offenders the same?: An empirical and theoretical critique of a recently proposed general theory of crime. Journal of Research in Crime and Delinquency, 29, 251-272.

Blumstein, A., Cohen, J., Roth, J. A., \& Visher, C. A. (1986). Criminal careers and “career criminals.” Washington, DC: National Research Council.

Braithwaite, J. (1984). Corporate crime in the pharmaceutical industry. London: Routledge \& Kegan Paul.

Calavita, K., \& Pontell, H. N. (1990). "Heads I win, tails you lose": Deregulation, crime, and crisis in the savings and loan industry. Crime \& Delinquency, 36, 309341.

Clinard, M. B., \& Quinney, R. (1973). Criminal behavior systems: A typology. New York: Holt, Rinehart \& Winston.

Cohen, L. E., \& Felson, M. (1979). Social change and crime rate trends: A routine activities approach. American Sociological Review, 44, 588-608.

Coleman, J. W. (1998). The criminal elite: Understanding white-collar crime. New York: St. Martin's Press.

Cressey, D. (1953). Other people's money. New York: Free Press.

Croall, H. (1989). Who is the white-collar criminal? British Journal of Criminology, 29, 157-174.

Daly, K. (1989). Gender and varieties of white-collar crime. Criminology, 27, 769794.

Elder, G. H., Jr. (1994). Time human agency and social change. Social Psychology Quarterly, 57, 4-15.

Elliot, D. S. (1994). Serious violent offenders: Onset, developmental course and termination. Criminology, 32, 1-22.

Farrington, D. (1992). Criminal career research in the United Kingdom. British Journal of Criminology, 32, 521-536.

Forst, B., \& Rhodes, W. (n.d.). Sentencing in eight United States District Courts, 1973-1978. Codebook (Interuniversity Consortium for Political and Social Research Study No. 8622). Ann Arbor: University of Michigan.

Geis, G. (1977). The heavy electrical equipment antitrust cases of 1961. In G. Geis \& R. Meier (Eds.), White-collar crime (Rev. ed., pp. 117-132). New York: MacMillan.

Gottfredson, M. R., \& Hirschi, T. (1990). General theory of crime. Stanford: Stanford University Press.

Gould, S. J. (2002). The structure of evolutionary theory. Cambridge, MA: Harvard University Press.

Hagan, J. (1997). Defiance and despair: Subcultural and structural linkages between delinquency and despair in the life course. Social Forces, 76, 119-134.

Hagan, J., \& Palloni, A. (1998). Crimes as social events in the life course: Reconceiving a criminological controversy. Criminology, 26, 87-100.

LeBlanc, M., \& Loeber, R. (1998). Developmental criminology updated. In M. Tonry (Ed.), Crime and justice: A review of research (pp. 115-198). Chicago: University of Chicago Press. 
Moffitt, T. E. (1993). Adolescence-limited and life-course-persistent antisocial behavior: A developmental taxonomy. Psychological Review, 100, 674-701.

Moffitt, T. E. (1997). Adolescence-limited and life-course persistent offending: A complementary pair of developmental theories. In T. P. Thornberry (Ed.), Developmental theories of crime and delinquency (pp. 11-54). New Brunswick, NJ: Transaction Publishers.

Moffitt, T. E., Caspi, A., Rutter, M., \& Silva, P. A. (2001). Sex differences in antisocial behaviour: Conduct disorder, delinquency, and violence in the Dunedin longitudinal study. Cambridge: Cambridge University Press.

Nagin, D. S., \& Land, K. C. (1993). Age, criminal careers, and population heterogeneity: Specification and estimation of a nonparametric, mixed Poisson model. Criminology, 31, 327-362.

Patterson, G. R., DeBaryshe, B., \& Ramsey, E. (1989). A developmental perspective on antisocial behavior. American Psychologist, 44, 329-335.

Piquero, A. R., Farrington, D. P., \& Blumstein, A. (2003). The criminal career paradigm. In M. Tonry (Ed.), Crime and justice: A review of research (pp. 359-506). Chicago: University of Chicago Press.

Reed, G. E., \& Yeager, P. C. (1996). Organizational offending and neoclassical criminology: Challenging the reach of a general theory of crime. Criminology, 34, 357-382.

Sampson, R. J., \& Laub, J. H. (1993). Crime in the making. Cambridge: Harvard University Press.

Simpson, S. S., \& Koper, C. S. (1992). Deterring corporate crime. Criminology, 30, 347-375.

Simpson, S. S., \& Piquero, N. L. (2000). The Archer Daniels Midland antitrust case of 1996: A case study. In H. N. Pontell \& D. Shichor (Eds.), Contemporary issues in crime and criminal justice: Essays in honor of Gilbert Geis (pp. 175-194). Upper Saddle River, NJ: Prentice Hall.

Simpson, S. S., \& Piquero, N. L. (2002). Low self-control, organizational theory, and corporate crime. Law and Society Review, 36, 509-548.

Sutherland, E. H. (1940). White collar criminality. American Sociological Review, 5, $1-12$.

Sutherland, E. H. (1949). White-collar crime. New York: Holt, Rinehart \& Winston.

Thornberry, T. P. (1987). Toward an interactional theory of delinquency. Criminology, 25, 863-892.

Thornberry, T. P., \& Krohn, M. D. (2003). Taking stock of delinquency: An overview of findings from contemporary longitudinal studies. New York: Kluwer Academic/ Plenum Publishers.

Vold, G. B., Bernard, T. J., \& Snipes, J. B. (1998). Theoretical criminology. New York: Oxford University Press.

Weisburd, D., \& Waring, E. (2001). White-collar crime and criminal careers. New York: Cambridge University Press.

Weisburd, D., Wheeler, S., Waring, E., \& Bode, N. (1991). Crimes of the middle classes: White-collar offenders in the federal courts. New Haven, CT: Yale University Press. 
West, D. J., \& Farrington, D. P. (1977). The delinquent way of life. London: Hienemann.

Wheeler, S. (1992). The problem of white-collar crime motivation. In K. Schlegel \& D. Weisburd (Eds.), White-collar crime reconsidered (pp. 108-123). Boston: Northeastern University Press.

Wheeler, S., Weisburd, D., Waring, E., \& Bode, N. (1988). White collar crime and criminals. American Criminal Law Review, 25, 331-357.

Zeitz, D. (1981). Women who embezzle or defraud: A study of convicted felons. New York: Praeger.

Nicole Leeper Piquero is an Assistant Professor of Criminology at the University of Florida. Her research interests include corporate/white-collar crime and criminological theory. Publications have appeared in Law and Society Review, Justice Quarterly, and Journal of Criminal Justice. She is currently working on a National Institute of Justice funded research project investigating the causes and prevention of intellectual property crimes.

Michael L. Benson is Professor of Criminal Justice at the University of Cincinnati. His book, Crime and the Life Course: An Introduction, was published in 2002 by Roxbury Press. He is currently working on a book on white-collar crime and opportunity theory. 